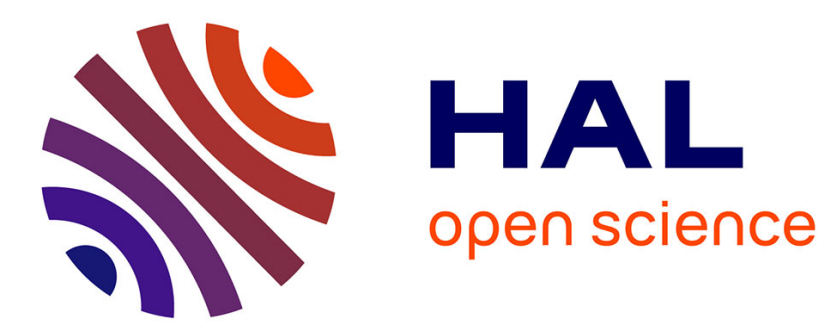

\title{
Helical twisting in reentrant nematic mixtures with optically active dopants
}

\author{
G.S. Chilaya, C. Destrade, Z.M. Elashvili, S.P. Ivchenko, L.N. Lisetski, \\ Nguyen Huu Tinh, K.D. Vinokur
}

\section{- To cite this version:}

G.S. Chilaya, C. Destrade, Z.M. Elashvili, S.P. Ivchenko, L.N. Lisetski, et al.. Helical twisting in reentrant nematic mixtures with optically active dopants. Journal de Physique Lettres, 1985, 46 (2), pp.75-78. 10.1051/jphyslet:0198500460207500 . jpa-00232480

\section{HAL Id: jpa-00232480 https://hal.science/jpa-00232480}

Submitted on 1 Jan 1985

HAL is a multi-disciplinary open access archive for the deposit and dissemination of scientific research documents, whether they are published or not. The documents may come from teaching and research institutions in France or abroad, or from public or private research centers.
L'archive ouverte pluridisciplinaire HAL, est destinée au dépôt et à la diffusion de documents scientifiques de niveau recherche, publiés ou non, émanant des établissements d'enseignement et de recherche français ou étrangers, des laboratoires publics ou privés. 
Classification

Physics Abstracts

$61.30-64.70 \mathrm{M}$

\title{
Helical twisting in reentrant nematic mixtures with optically active dopants
}

\author{
G. S. Chilaya $\left({ }^{*}\right)$, C. Destrade $\left({ }^{+}\right)$, Z. M. Elashvili (*), S. P. Ivchenko $\left({ }^{*}\right)$, L. N. Lisetski $\left(^{*}\right)$, \\ Nguyen Huu Tinh $\left(^{+}\right)$and K. D. Vinokur $\left(^{*}\right)$ \\ (*) Institute of Cybernetics of Academy of Sciences of Georgian S.S.R., S. Euli str. No 5, \\ Tbilissi 380086, U.S.S.R. \\ $\left({ }^{+}\right)$Centre de Recherche Paul Pascal, Domaine Universitaire, 33405 Talence Cedex, France
}

(Reçu le 3 octobre 1984, accepté le 22 novembre 1984)

\begin{abstract}
Résumé. - Des systèmes cholestériques présentant un mésomorphisme rentrant ont été obtenus en dopant un mélange possédant une phase nématique rentrante avec des substances optiquement actives comme des dérivés de la tygogenyne et du 1-menthol. Le déroulement de l'hélice cholestérique a été observé à l'approche de la transition $\mathrm{T}_{\mathrm{Ch}}-\mathrm{S}_{\mathrm{A}}$ dans les phases cholestériques haute et basse température. L'influence de la concentration du dopant sur la stabilité de la phase smectique intermédiaire et sur la valeur du pas cholestérique est discutée.
\end{abstract}

\begin{abstract}
Induced cholesteric systems with reentrant mesomorphism were observed by doping reentrant nematic mixtures with optically active tygogenyn and l-menthol derivatives. Helix unwinding was observed on approaching $\mathrm{T}_{\mathrm{Ch}}-\mathrm{S}_{\mathrm{A}}$ in both cholesteric phases. Influence of the dopant concentration upon the stability of the intermediate smectic phase and helical pitch is discussed.
\end{abstract}

\section{Introduction.}

Since its discovery by Cladis [1], the reentrant phenomenon has attracted considerable attention, and a number of systems with such properties have been investigated [2,3]. It is generally agreed that the physical properties of both nematic phases are roughly similar [4], although some quantitative differences have been pointed out, e.g. the values of the activation energy [5] and of the orientational order parameter are noticeably higher in the $\mathrm{N}_{\text {re }}$ phase, presumably due, in the last case, to lower temperature [6]. So it was a natural attempt to induce helical twisting in reentrant mixtures. With sufficiently high concentrations of optically active dopants selective reflexion in the visible range was reported [7]; later on, pure chiral reentrant nematics were synthesized [8]. A search for new systems is going on, with the study of the influence of the dopant nature on the thermal stability of the intermediate smectic phase [9].

In the present paper we report helical pitch temperature and concentration dependences in both cholesteric phases for reentrant nematics with optically active dopants. 


\section{Experimental.}

We have chosen a reentrant nematic mixture of the following composition :

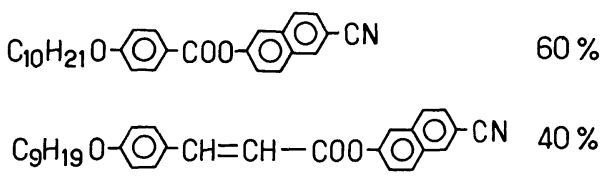

The mixture displays reentrant mesomorphism [2] with large temperature ranges for all the phase of interest :

$$
\mathrm{K} \stackrel{62^{\circ}}{\rightarrow} \mathrm{N}_{\mathrm{re}} \stackrel{75^{\circ}}{\rightleftharpoons} \mathrm{S}_{\mathrm{A}} \stackrel{153^{\circ}}{\rightleftharpoons} \mathrm{N} \stackrel{173^{\circ}}{\rightleftharpoons} \mathrm{I}
$$

In all our experiments we used tygogenyn caprinate (TC) [10].

This substance was used in some of our earlier work to induce helical twisting in nematic matrices [10] and proved itself to be an effective optically active dopant. We have performed some experiments with other optically active dopants but it is clear that introducing the same amount of 1-menthyl-p-methoxy cinnamate instead of $5 \% \mathrm{TC}$ caused the reentrant cholesteric phase to disappear and the thermal stability of the smectic phase to decrease. Helical pitch $p$ values were determined by the technique of Bragg diffraction on the focal conic texture [10,11] for $p \gtrsim 1 \mu \mathrm{m}$ and by selective reflexion spectra from the planar texture for $p=0.2-0.5 \mu \mathrm{m}$. Phase transition temperatures were determined through a polarizing microscope.

\section{Results and discussion.}

Figure 1 shows how TC concentration affects the intermediate smectic phase existence range. One should note that this influence is rather complicated with $\mathrm{TC}$ in the concentration range $3-8 \%$ inducing no decrease in the thermal stability of the intermediate $S_{A}$ phase. This behaviour is difficult to explain : as a matter of fact the TC compound is non-mesogenic, and its molecular structure [10] differs greatly from that of the nematic matrix. One may assume that this rather unexpected behaviour is due to some specific interactions between the molecules of the matrix and the dopant; in any case, there is a need for further investigations on this comportment.

In figure 2 we give the helical pitch temperature dependences for the different systems studied.

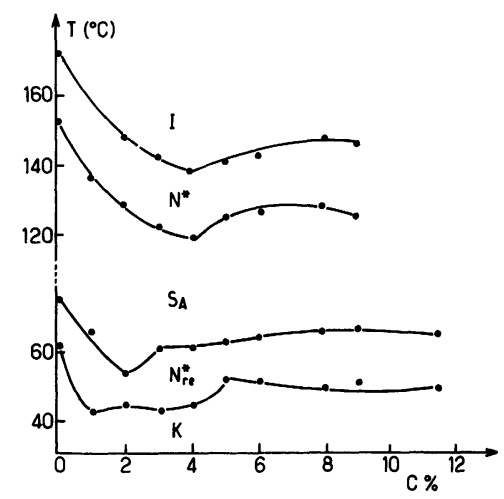

Fig. 1. - Influence of the TC concentration $(\%)$ on the mesomorphic behaviour. 


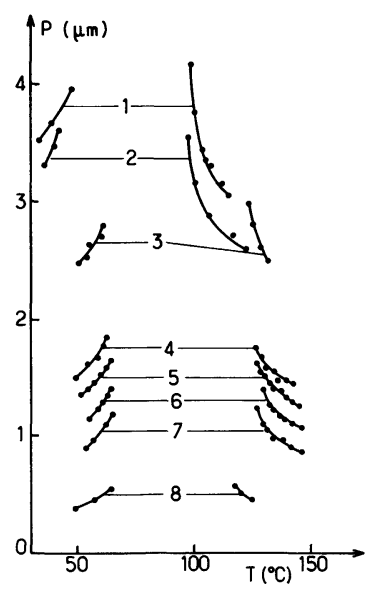

Fig. 2. - Helical pitch temperature dependences for the different studied mixtures. Numbers 1-8 correspond to TC concentration.

Following the predictions of Billard [7] we have definitely demonstrated the helix unwinding in both low and high temperature cholesteric phase on approaching the cholesteric to smectic A transition. Moreover, in the low temperature cholesteric phase, the $p(T)$ curves are found to be not so steep, presumably reflecting an influence of the TC rotational vibration anharmonicity. The induced cholesteric systems comprising non-smectogenic nematics and tygogenyn derivatives are characterized by their negative $\frac{\mathrm{d} p}{\mathrm{~d} T}$ values [9]. At last, the variation of the inverse pitch $p^{-1}$ with the TC concentration is given in figure 3 . Within experimental errors, the plots obtained are linear, as is usually observed for induced cholesteric systems.

\section{Conclusion.}

In this paper we have given the first quantitative measurement of the temperature dependence of the helical cholesteric pitch in a cholesteric reentrant mixture. From a practical point of view let us point out that some of the mixtures exhibit a low temperature reentrant cholesteric phase, near room temperature, for which the pitch variation against temperature is opposite to classical systems. This property will probably, as reported elsewhere [12], stimulate the fabrication of liquid crystalline thermo-indicators giving blue light reflexion at low temperature and red one at high temperature.

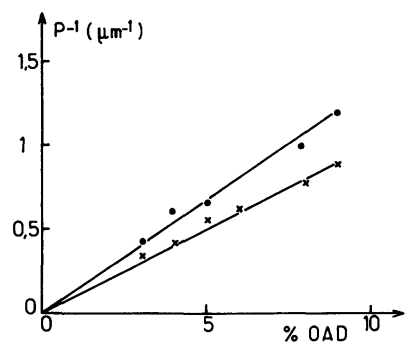

Fig. 3. - Variation of the inverse pitch $\left(p^{-1}\right)$ with the TC concentration (OAD $=$ Optically Active Dopant). 


\section{References}

[1] Cladis, P. E., Phys. Rev. Lett. 35 (1975) 48.

[2] Nguyen HuU Tinh, Mol. Cryst. Liq. Cryst. 91 (1983) 285.

[3] Nguyen Huu Tinh, J. Chem. Phys. et Phys. Chim. Biol. 80 (1983) 83.

[4] Hardouin, F., Sigaud, G., Achard, M. F., Gasparoux, H., Solid State Commun. 30 (1979) 265.

[5] Legrand, C., Parneix, J. P., Chapoton, A., Nguyen Huu Tinh, Destrade, C., J. Physique 45 (1984) L-283.

[6] Miyajina, S., Akaba, K., Chiba, T., Solid State Commun. 49 (1984) 695.

[7] Billard, J., C.R. Hebd. Séan. Acad. Sci. Paris C 292 (1981) 881.

[8] Nguyen Huu Tinh, Destrade, C., Malthete, J., Jacques, J., Mol. Cryst. Liq. Cryst. Lett. 72 (1982) 195.

[9] Vaz, N. A. P., Yaniv, Z., Doane, J. W., Mol. Cryst. Liq. Cryst. Lett. 92 (1983) 75.

[10] Chilaya, G. S., Elashvili, Z. M., Lisetski, L. N., Piliashvili, T. S., Vinokur, K. D., Mol. Cryst. Liq. Cryst. 74 (1981) 261.

[11] KaHn, F. J., Phys. Rev. Lett. 24 (1970) 209.

[12] Dubois, J. C. et al., Patent Thomson-CSF no 8018774 (1980). 